\title{
Landslides in the marly slope of the Kapsali area in Kithira Island, Greece
}

\author{
B. Christaras $\cdot$ M. Argyriadis $\cdot$ E. Moraiti
}

Received: 9 August 2012/ Accepted: 18 July 2013/Published online: 25 January 2014

(C) The Author(s) 2014. This article is published with open access at Springerlink.com

\begin{abstract}
In April 2004, the uphill area of the touristic Kapsali Golf, in the southern part of Kithira Island was affected by large-scale landslides. These landslides, which also affected the road between Kapsali-Kalamos, occurred in ground consisting of marl, overlain by limestone. This investigation indicated that the back analysis method of study gave more realistic results than the original laboratory tests because it more effectively factors the conditions at the time of ground failure-in particular, those parameters relating to the mechanical characteristics $c$ and $\Phi$ of the substrate material. The natural slope of the marl-rich substrate presents a limited stability; this stability decreases during heavy rainfall. The cause of the slides investigated is the interaction between the silty clayey (CL-ML) substrate and heavy rainfall. The low porosity of the substrate impedes the slope drainage which in turn leads to saturated, unstable ground. The potential for new slides to occur in the area is real if no protective measures are taken.
\end{abstract}

Keywords Landslides $\cdot$ Marly $\cdot$ Marls $\cdot$ Silty-materials

\footnotetext{
B. Christaras ( $\square)$

School of Geology, Aristotle University of Thessaloniki, 54124 Thessaloniki, Greece

e-mail: christar@geo.auth.gr

M. Argyriadis

Argyriadis and Collaborators, Geotechnical Studies,

9, Evrou Str., 18345 Piraeus, Greece

e-mail: argyri@otenet.gr

E. Moraiti

Institute of Geology and Mineral Exploration (IGME), Olympic

Village, 13677 Acharnai, Greece

e-mail: moraiti@igme.gr
}

\section{Introduction}

The basis of this investigation is the use of a back analysis technique to enable a realistic slope stability analysis. Using this framework, derived data of possible $c$ and $\Phi$ values, were used for investigating other neighbouring sites underlain by marly, fine-grained sediments (Christaras et al. 2011) (Fig. 1).

The study area, located at the southern part of Kithira Island, includes the uphill area of the Kapsali Golf and part of the road which connects Kapsali village with Kalamos village, the capital of the island. The landslides described, occurred in marls overlain by limestones (Danamos 1992).

The ground immediately above Kapsali village, consists of partially weathered, marls with occasional thin sandstone intercalations (Fig. 2). The marl comprises low plasticity, silty clay (with occasional low percentages of sand). These stratified sediments have a direction of dip and dip angle of 280/35. The uppermost part of the hillside (called the "Plateau") comprises calcareous conglomerates (Fig. 3); these sediments overlie the marls. Structurally, the area is divided into large blocks constrained by E-W and NW-SE trending vertical joints. Two NW trending faults limit the northern part of the area. This local structure forms part of the general tectonic framework of Kithira Island (Danamos 1992). In addition, the island is subject to high seismotectonic activity as it forms part of the western Greek arc; during the period 1750 to 1937 , earthquakes of magnitude $M=6.0-7.2$ were recorded (Papazachos and Papazachou 2002).

\section{Slope stability analysis}

As noted, the slope in question consists of marls overlain by calcareous conglomerates. The landslides occurred 


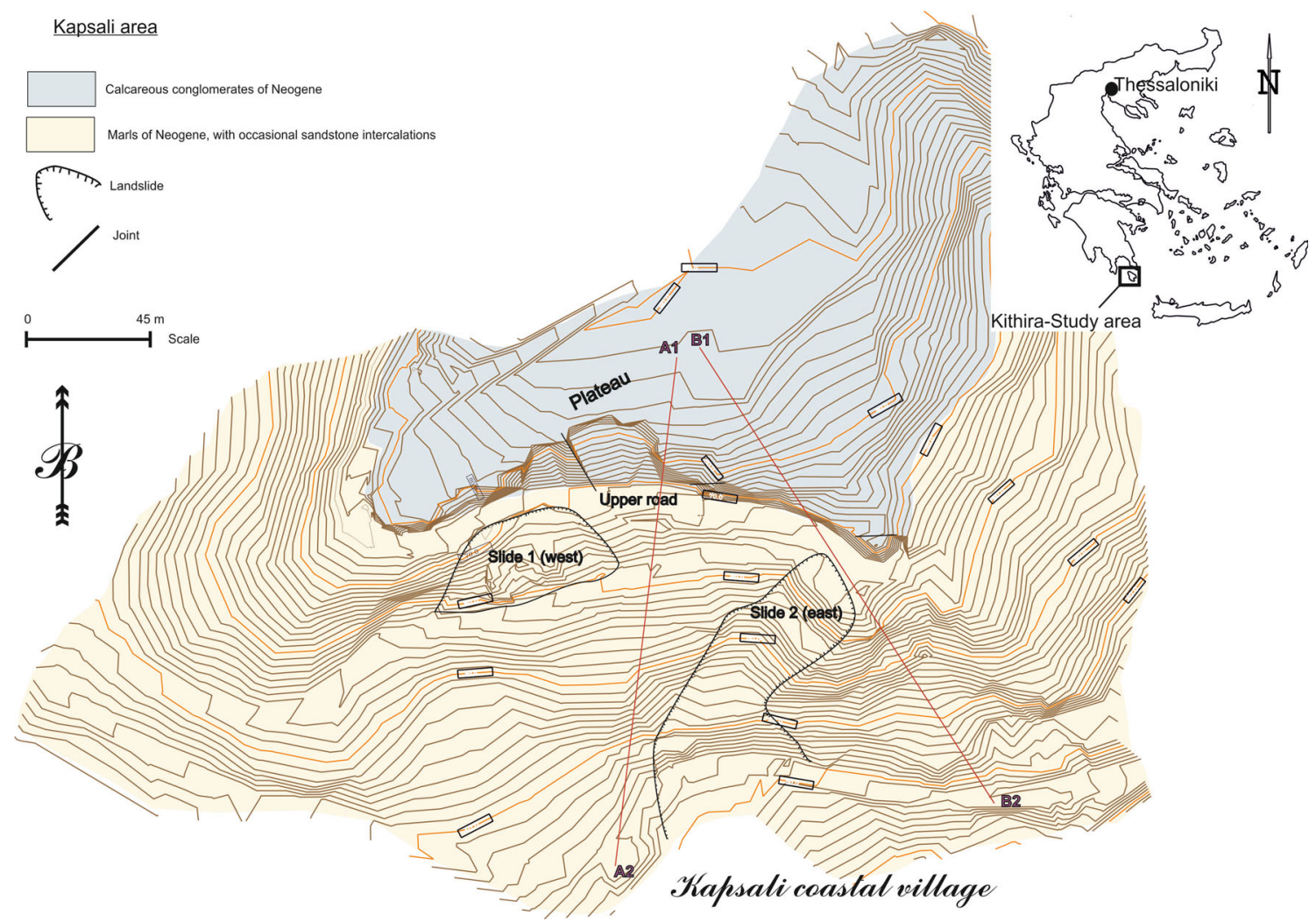

Fig. 1 Geological sketch with the location of the landslides and the studied cross sections $\left(A_{1}-A_{2}\right.$ and $\left.B_{1}-B_{2}\right)$

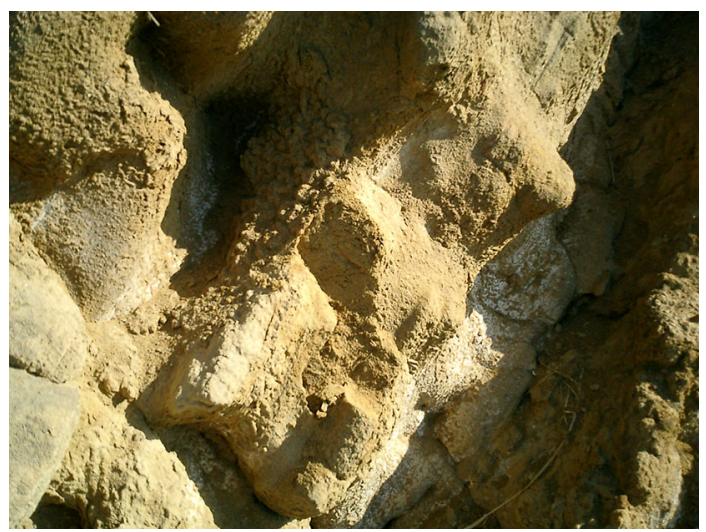

Fig. 2 Marl-rich sediments of Neogene age. Note the interbedded, inclined sequence of sandstone and partially weathered marl

within the marl-rich sequence and stratigraphically below the conglomerates, which, consequently, were not affected by the slides (Fig. 1). The marl is generally weathered and in many instances, gives the impression of being a soil. Under dry conditions, the material is hard and cohesive but subject to wet conditions, it rapidly looses its cohesion. The water penetration is low, approximately $10^{-6} \mathrm{~cm} / \mathrm{s}$, if it is counted taking, into account, its grain size distribution $\left(k=100 \times \mathrm{d}_{10}^{2}=100 \times 0.001^{2}=0.0001 \mathrm{~mm} / \mathrm{s}=10^{-6}\right.$ $\mathrm{cm} / \mathrm{s})$. The landslides are totally located within the marl

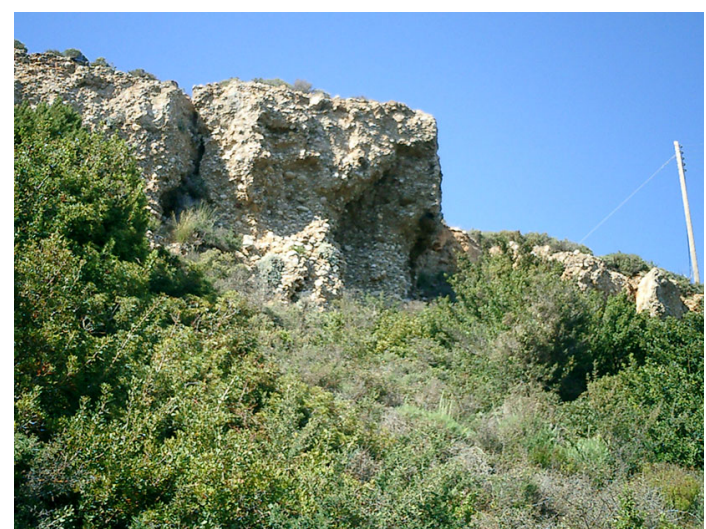

Fig. 3 Calcareous conglomerate of Neogene age. This "Plateau" sequence overlies the marls within which the landslides developed

sequence and locally, cut across the road to Kapsali village (Fig. 4). In Fig. 5, the toe of the eastern slide (slide 2) is illustrated.

According to our laboratory tests, the material is characterized as silty clay (CL-ML) of low plasticity, having (a) clay: $14.31 \%$, (b) silt: $74.56 \%$, (c) sand: $11.13 \%$, (d) LL: 11, (e) PL: 5, (f) PI: 6, (g) $\Phi=23.2^{\circ}$, and (h) $c=0.227 \mathrm{~kg} / \mathrm{cm}^{2}$. The cohesion ${ }^{\odot}$ and internal friction ( $\Phi)$ parameters were calculated using the GDS electronic triaxial system of our laboratory, of Engineering Geology 


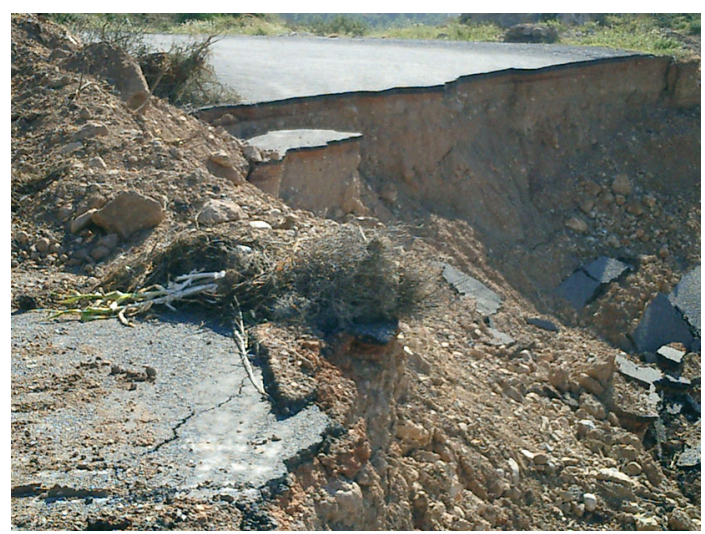

Fig. 4 The crest of the eastern sliding "slide 2"

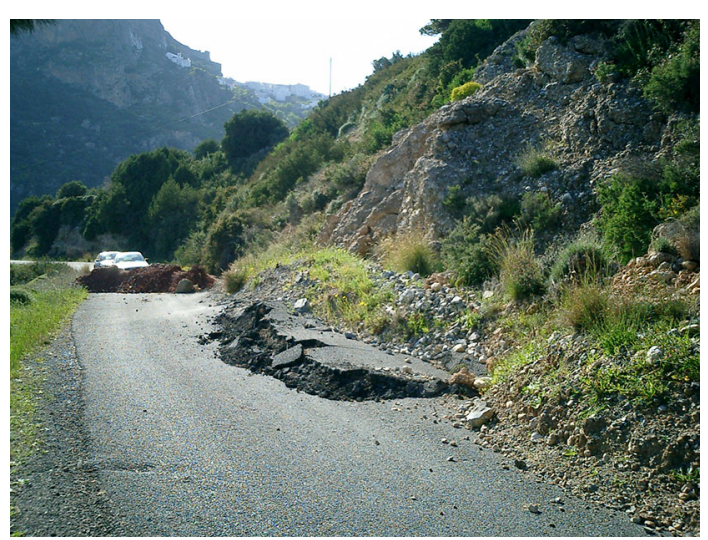

Fig. 5 The toe of the western sliding "slide 1"

and Hydrogeology, School of Geology, and of Aristotle University of Thessaloniki (AUTH).

The slope stability analysis was performed using various methodologies namely, that of Bishop (1955) and of Morgenstern and Price (1965) Geoslope software (student version of 2002) was also used, which gave similar results. In the present description, the Morgenstern and Price (1965) method was used.

According to our laboratory test results, the slope presents sliding circles of limited stability, with limited values $\mathrm{FS}_{\text {min }}=1.05-1.3$, estimated for dry conditions. These coefficients decrease under 1 (slide west: $\mathrm{FS}_{1}=0.993$ and slide east: $\mathrm{FS}_{2 \text { up }}=0.958$ and $\mathrm{FS}_{2 \text { low }}=0.996$ ) in rain conditions, according to our back analysis test calculations, after in situ observations.

The estimation of cohesion $(c)$ and internal friction of the marl $(\Phi)$, at the time of failure, was performed using back analysis method for slope stability estimation. The method accepts, necessarily, the marl as homogeneous, even though there are occasional thin sandstone intercalations, accepting $c$ and $\Phi$ values which correspond to the failure moment.
According to the back analysis data, we estimated for marl a possible pair of parameters $c=4 \mathrm{kN} / \mathrm{m}^{2}$ and $\Phi=18^{\circ}$. These values are very low, related to an estimated moisture of $15 \%$ which gives an apparent weight of $23 \mathrm{kN} / \mathrm{m}^{3}$.

Using the back analysis data at the site of slides 1 and 2, a new slope stability analysis was performed in the marly slope, along with a similar analysis for the section lines $A_{1}-A_{2}$ and $B_{1}-B_{2}$ (Fig. 1), located very near to the forementioned slides (Fig. 1). This comparative analysis assumed that the mechanical behavior of the marl-rich sediments does not change across the slope. Whilst the slope substrate did not show any clear slide geometry, the upper part of the soil showed signs of moving down-slope; therefore, the marl is considered as not being a stable material for practicable purposes.

As previously mentioned, the safety factor (SF) of the marl-rich slope, readily decreases to under factor "1" during prolonged rainfall, with the slope becoming unstable.

\section{Slide 1 (western part of the slope)}

The crest of the landslide is located at a height of $71 \mathrm{~m}$ (Figs. 1, 6) whilst the toe at a height of $62 \mathrm{~m}$ (Figs. 1, 5, 6). The landslipped mass covers an area of about $1,800 \mathrm{~m}^{2}$, and is circular with an arc of $60 \mathrm{~m}$ and W-SW direction. This rotational movement created a backscar wall $2.5 \mathrm{~m}$ high and a horizontal opening of $0.5-1.5 \mathrm{~m}$. In order to estimate the cohesion $(c)$ and the internal friction $(\Phi)$ of the marl and to perform the slope stability analysis, we used the back analysis technique parameters for saturated ground; this approach simulates the rainfall conditions prevalent at the time of the landslides. From this, we arrived at the following data: $c=4 \mathrm{kN} / \mathrm{m}^{2}$ and $\Phi=18^{\circ}$, for the given landslide geometry and safety factor $\mathrm{SF}=0.993$.

The values used above were also verified in the eastern slide (Slide 2). It is worth mentioning here that several slide rotation circles are possible for the western slide setting; that shown in Fig. 6, equates to the slide that occurred. Thus, there is the possibility that a larger slide may occur if the slope stability is not improved by some means.

All the above estimations and calculations used in situ surface observations. We did not have the opportunity to obtain borehole data. Despite this, the results obtained seemed to approximate to the actual slide parameters.

\section{Slide 2 (eastern part of the slope)}

This slide comprises two parts. The crest of the uppermost subslide is located at a height of $70 \mathrm{~m}$ (Figs. 1,4,7) while its 


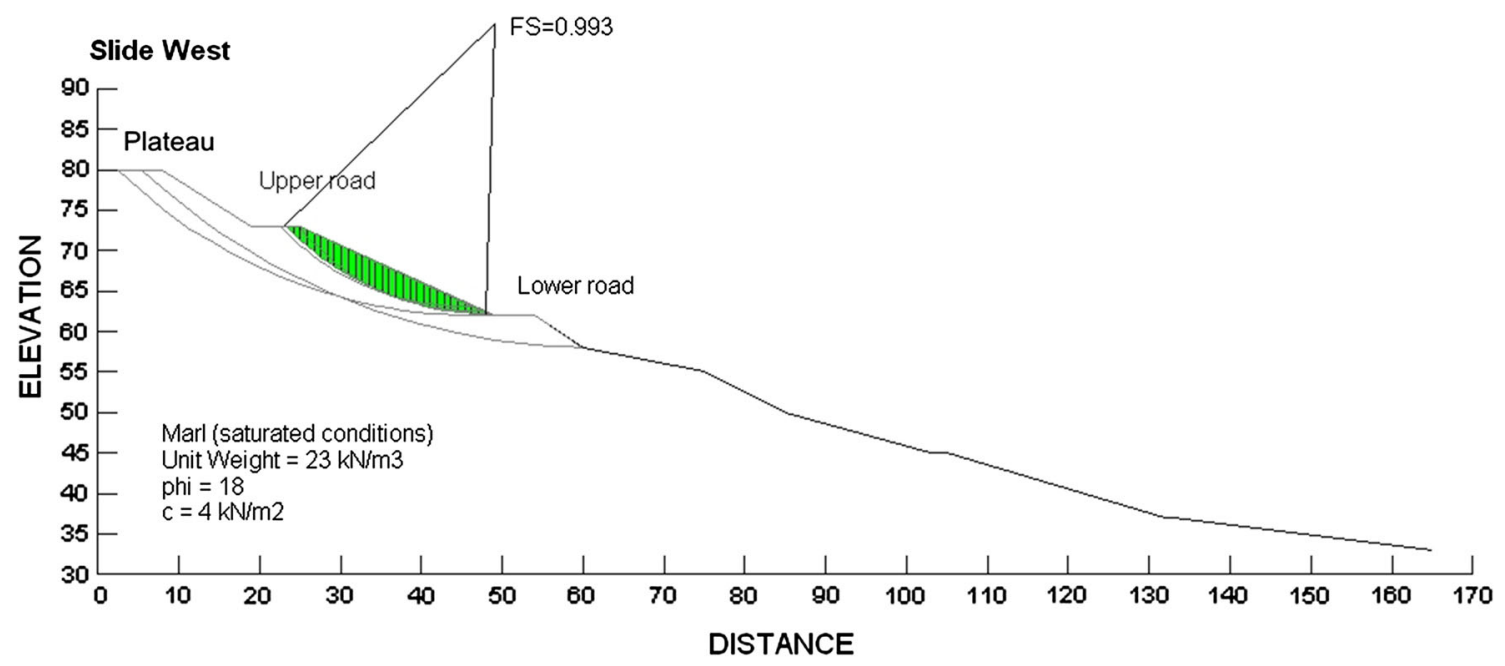

Fig. 6 Slope stability analysis of "slide 1" using back analysis technique

\section{Slide East}

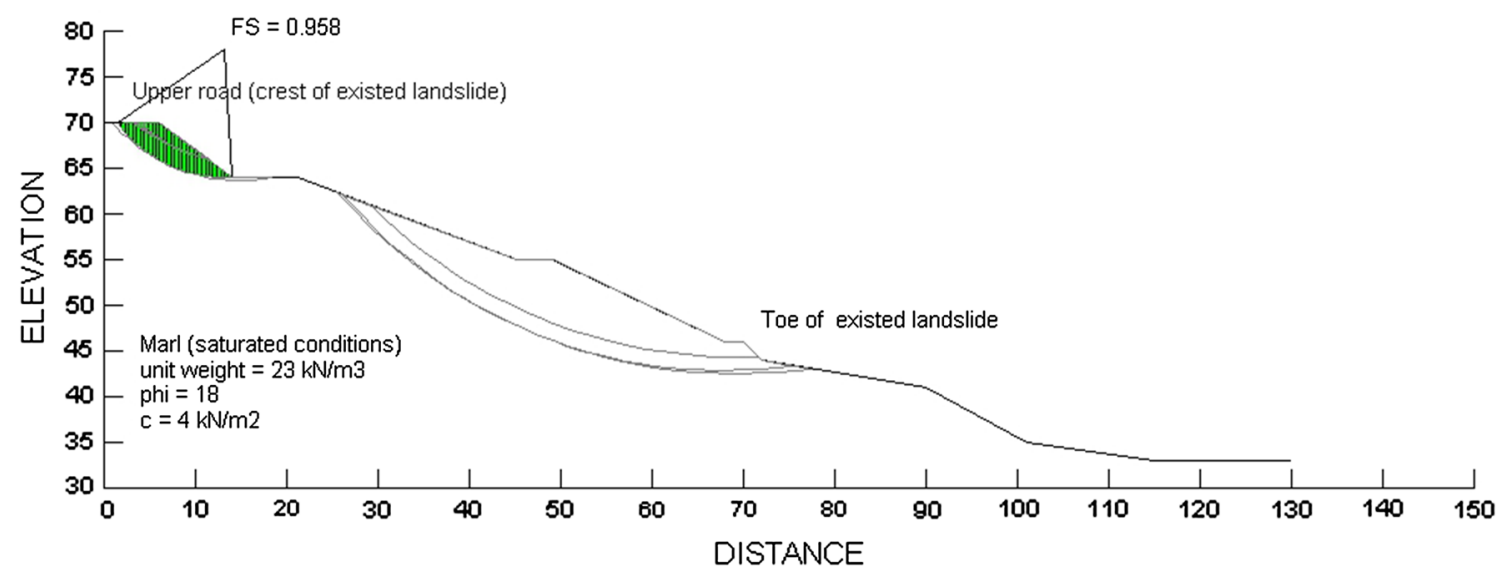

Fig. 7 Slope stability analysis at the upper part of the eastern slide (slide 2), using back analysis technique

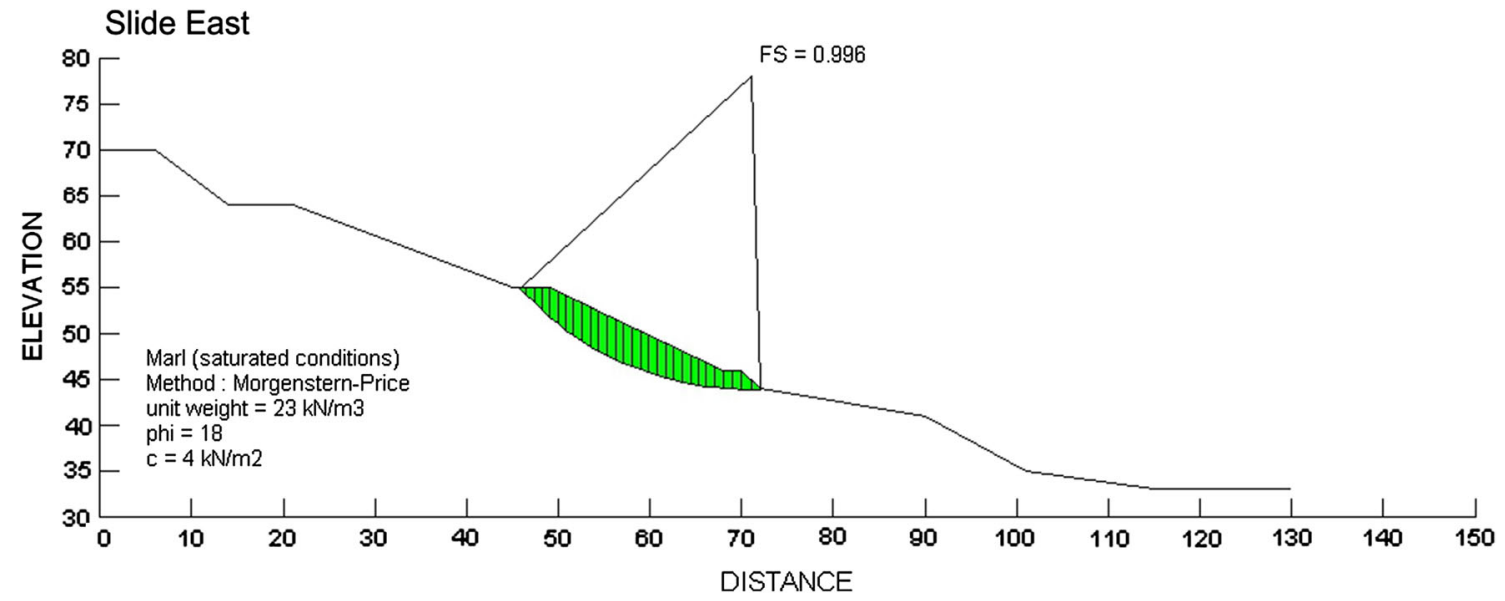

Fig. 8 Slope stability analysis at the lower part of the eastern slide (slide 2), using back analysis technique 


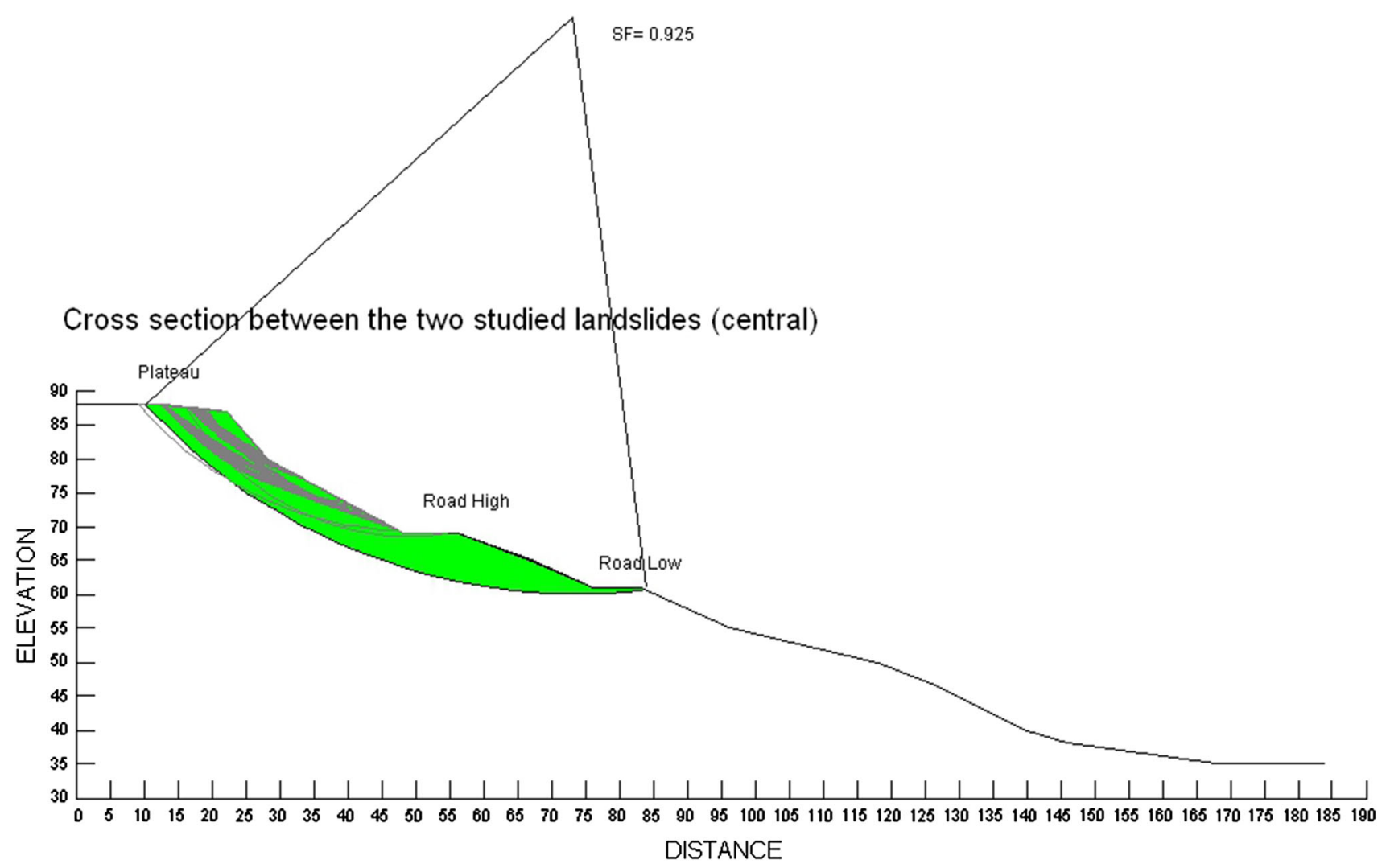

Fig. 9 Slope stability analysis along the axis: A1-A2, using back analysis data

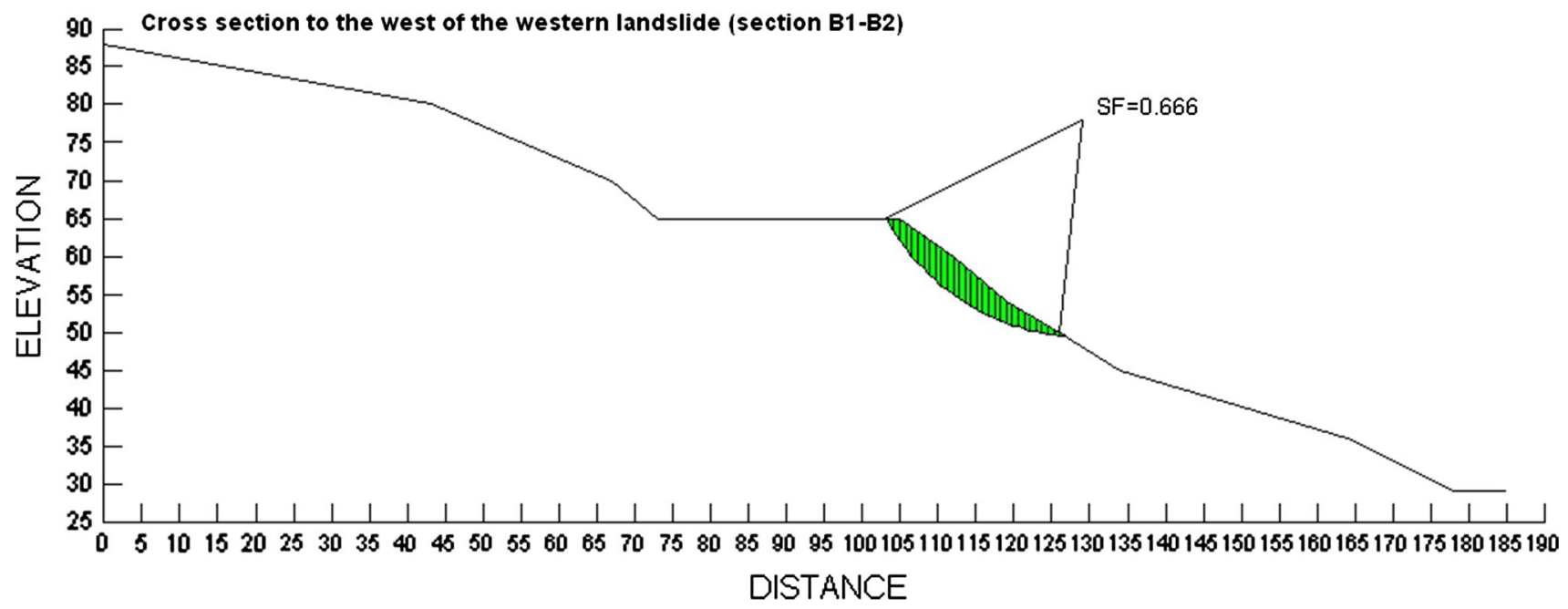

Fig. 10 Slope stability analysis along the axis: B1-B2, using back analysis data

toe lies at a height of $64 \mathrm{~m}$ (Figs. 1, 7). The crest of the second, lower sub-slide is located at a height of $55 \mathrm{~m}$ while its toe lies at a height of $44 \mathrm{~m}$, not far from some houses. The landslipped mass covers an area of about $3,000 \mathrm{~m}^{2}$ with a width of $45 \mathrm{~m}$. The slippage was towards the S-SW. The vertical displacement at the crest of the slide was $5 \mathrm{~m}$ (Fig. 8).
Working on the basis of saturated ground conditions (as for Slide 1), we arrived at the following data: $c=4 \mathrm{kN} / \mathrm{m}^{2}$ and $\Phi=18^{\circ}$, These parameters gave a safety factor $\mathrm{SF}=0.958$, for the uppermost sub-slide, and $\mathrm{SF}=0.996$, for the second, lower subslide. 


\section{Slope stability analysis along section lines A1-A2 and B1-B2}

The results of back analysis tests were used for analysing the slope stability along the selected lines of section A1A2 and B1-B2 (Fig. 6).

According to our calculations, the slide rotation circles give the following safety factors: for $\mathrm{A} 1-\mathrm{A} 2 \mathrm{:} \mathrm{SF}=0.926$ and $\mathrm{B} 1-\mathrm{B} 2: \mathrm{SF}=0.66$. The $\mathrm{SF}$ values are very low, because although the material is considered as saturated, this saturation is mainly restricted to superficial layers which does not result in clear, distinct landslides (Figs. 9, $10)$.

\section{Slope instability in silty clays and marly formations}

- The geological setting and underlying marl-rich sediments of the Kapsali area, present good stability during dry conditions. However, these marls lose both cohesion and their stability (the latter rapidly-logarithmically), during prolonged rainfall or sustained wet conditions. The saturation characteristics of the Kapsali silty-clay marls, is also ascribed to the siltstones lying beneath Metsovo City, Greece, at sites where the Egnatia highway passes (Christaras et al. 1996), Other examples include the marls of the Eptachory area (Christaras 1997), and the marly formations of the archaeological site of Olympia (Christaras et al. 2002).

\section{Discussion and conclusion}

Based on our investigation, we conclude that:

- The studied landslides occurred in silty clayey (CLML) sediments which constitute the main geological formation underlying the Kapsali area of Kithira Island. A characteristic of this low porosity, marl-rich material (due to its fine grain size), is that it surfical layers rapidly become saturated (with unsaturated, inner core layers), when exposed to prolonged rainfall.

- With regard to those landslides studied at Kapsali, the back analysis method provided more realistic results than the original laboratory tests because it takes into consideration the conditions at the time of failure. This finding refers in particular to the mechanical characteristic parameters $c$ and $\Phi$ of the marl-rich sediments.

- The sediments underlying the Kapsali area present good stability in dry conditions but rapidly lose their cohesive strength and thus, rock mass stability after exposure to prolonged rainfall.

Open Access This article is distributed under the terms of the Creative Commons Attribution License which permits any use, distribution, and reproduction in any medium, provided the original author(s) and the source are credited.

\section{References}

Bishop AW (1955) The use of the slip circle in the stability analysis of slopes. Geotechique 1:7-17

Christaras B (1997) Landslides in iliolitic and marly formations. Examples from the North-western Greece. Engineering Geology, vol 47. Elsevier, Amsterdam, pp 57-69

Christaras B, Zouros N, Makedon TH, Dimitriou AN (1996) Common mechanism of landslide creation along the under construction Egnatia highway. In: Pindos mountain range (N. Greece). 30th IGC, Beijing, v.17

Christaras B, Mariolakos I, Dimitriou A, Moraiti E, Mariolakos D (2002) Slope instability at olympia archaeological site, in S. Greece. International Symposium of UNESCO landslides risk mitigation and protection of cultural and natural heritage, Kyoto, pp 339-342

Christaras B, Argyriadis M, Moraiti E (2011) Estimation of the stability of a marly slope, after raining. The case of Kapsali area, in Kithira Island. MAEGS 17 Proceedings, Belgrade

Danamos G (1992) Contribution to the geology and hydrogeology of Kithira Island. PhD Thesis, School of Geology, University of Athens, p 300

Morgenstern NR, Price VE (1965) The analysis of the stability of general slip surfaces. Geotechnique 15:79-93

Papazachos B, Papazachou K (2002) The earthquakes of Greece. In:

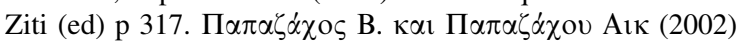

